\title{
Interactions among Tamarix (Tamaricaceae), Opsius stactogalus (Cicadellidae), and Litter Fungi Limit Riparian Plant Establishment
}

\author{
Gibney M. Siemion ${ }^{1}$, Lawrence E. Stevens ${ }^{2 *}$ \\ ${ }^{1}$ Grand Canyon Wildlands Council, Inc., Flagstaff, USA \\ ${ }^{2}$ Museum of Northern Arizona, Flagstaff, USA \\ Email: gibneysiemion@gmail.com,
}

Received 9 March 2015; accepted 22 April 2015; published 24 April 2015

Copyright (C) 2015 by authors and Scientific Research Publishing Inc.

This work is licensed under the Creative Commons Attribution International License (CC BY). http://creativecommons.org/licenses/by/4.0/

(c) (i) Open Access

\section{Abstract}

One of the most significant plant invasions in the U.S. has been that of the Old World genus Tamarix. While Tamarix spp. is widely studied, surprisingly little is known about more complex trophically-linked community mechanisms influencing under-canopy succession. We investigated multitrophic interactions among Tamarix spp., nonnative host-specific Opsius stactogalus leafhopper distribution and honeydew production, and the Tamarix spp. canopy floor fungal assemblage. We quantified leafhopper abundance and honeydew throughfall, and tested under-canopy seed viability and seedling mortality across a $1600 \mathrm{~m}$ elevation gradient in the lower Colorado River basin in 2007. We conducted field and laboratory experiments in 2007-08 to test the effects of Tamarix spp. litter fungi, synthetic honeydew, and the combination of those variables on germination and seedling survivorship of three common, co-occurring phreatophyte (riparian groundwater-dependent plant) species. Tamarix spp. litter and honeydew treatments reduced understory seed viability and recruitment of two native, woody riparian species (Populus fremontii and Baccharis salici$n a$ ), as well as Tamarix spp. Four major patterns were detected. 1) Litter fungi alone and synthetic honeydew alone reduced seed viability and seedling survivorship of all three species by two- to four-fold. 2) Synthetic honeydew + litter reduced Tamarix spp. and P. fremontii seed and seedling viability by up to 10 -fold. 3) Synthetic honeydew concentration and seedling mortality were positively related among all three plant species. 4) $B$. salicina was less susceptible to all treatments than Tamarix spp. and $P$. fremontii. These results indicate that complex interactions among nonnative Tamarix spp., nonnative Opsius leafhopper honeydew production, and soil fungi may influence riparian phreatophyte recruitment and succession.

\footnotetext{
*Corresponding author.
} 


\section{Keywords}

\section{Herbivore, Honeydew, Invasion Ecology, Multi-Trophic Interaction, Opsius stactogalus, Riparian, Tamarix}

\section{Introduction}

Nonnative plant species invasions are a global threat to biodiversity [1], and one of the most significant plant invasions in the U.S. has been that of the Old World genus Tamarix (Tamarix spp. hybrids of hybrids of T. ramosissima X T. chinensis, hereafter referred to as Tamarix spp.) [2]. Since its introduction in the 1800s, Tamarix spp. has escaped cultivation and hybrids have now invaded more than one million ha of riparian habitat in the western U.S. [3]. The deciduous Tamarix spp. under study here is distinguished from its congener, the evergreen antheltree T. aphylla, which is widely planted for shade and wind break at lower elevations in the American Southwest. There was a general increase in riparian vegetation throughout this region after the early 1900s [4], as Tamarix spp. invaded many riparian systems [2] [5]. Native riparian forests provide habitat, migration corridors, and terrestrial food resources for aquatic and riparian biota [6] [7]. In the arid Southwest, riparian habitats make up $<1 \%$ of the landscape area, yet support $>50 \%$ of the region's biota [8]. Anthropogenic influences, including flow regulation and livestock grazing, have limited recruitment of native phreatophytic riparian trees, such as Fremont cottonwood (Populus fremontii [7]), but have enhanced invasion of Tamarix spp. [2] [9] [10].

Natural riparian habitats in the southwestern U.S. often are dominated by native $P$. fremontii trees, with an understory of native shrub species, including Baccharis seepwillows. P. fremontii is an ecologically influential species and is the focus of much research due to its decline in regulated river systems [11] [12]. P. fremontii seedling recruitment decreased dramatically through the 20th Century in western states [7] [8], while nonnative Tamarix spp. cover increased from 1900 to 2005 [4], but is now decreasing due to biological control [13]. The native shrub, $B$. salicina, has received little ecological attention, but often is co-dominant with $P$. fremontii and Tamarix spp. along both regulated and unregulated streams [8] [10]. Elucidating trophic interactions that influence regeneration among these species in riparian ecosystems is relevant to understanding and management of southwestern riparian forest stand dynamics.

The tamarisk leafhopper [Cicadellidae: Opsius stactogalus (Fieber)] is a small $(4.0-4.5 \mathrm{~mm})$ leafhopper native to Eurasia, and is introduced to the U.S. on Tamarix spp. (Figure 1) [14]. It is host-specific and seasonally abundant on Tamarix spp., and has become a primary food source for neotropical migrant songbirds [15]. The leafhopper is multivoltine, with three to four generations per year, and it overwinters in the egg stage in Tamarix spp. shoots and woody stems [14]. After hatching, the leafhopper undergoes four instars before maturity [16]. $O$. stactogalus is one of several leafhoppers on Tamarix that produce honeydew in the Old World. Through feeding, the insect ingests phloem, extracting amino acids and other proteins necessary for growth and reproduction, while excreting the remaining carbohydrates as waste. The honeydew waste consists of low molecular weight sugars, with nitrogen constituting up to $2 \%$ of the total dry mass [17]. This energy-rich source of carbohydrates is biblically renowned as "manna", and is a consumable resource for soil and litter organisms [18]. The tamarisk leafhopper is the most abundant insect exuding honeydew on Tamarix spp. in northern Arizona, although two Chionaspis spp. diaspidid scale insects and two Parthenicus spp. mirid plant bugs also are common on Tamarix spp. in this region [19].

Despite vast expenditures on Tamarix spp. control in the Southwest, major gaps remain in understanding the ecological strategies by which Tamarix spp. colonizes and persists in riparian habitats [9]. Basic questions on the changing extent of Tamarix spp. distribution, its potential to alter community structure and function, its comparative life history characteristics, and applied questions regarding its influences on water use, responses to introduced biological control agents, and impacts on agriculture and recreation remain outstanding. In this paper, we report interactions among Tamarix spp., its host-specific Opsius cicadellid herbivore, and understory litter fungi that individually and interactively limit plant recruitment beneath Tamarix spp. canopy.

Complex multi-trophic interactions play an integral, but little appreciated role in riparian community development by limiting recruitment [20] [21]. Humans seeking shade under Tamarix spp. canopies in the Southwest 


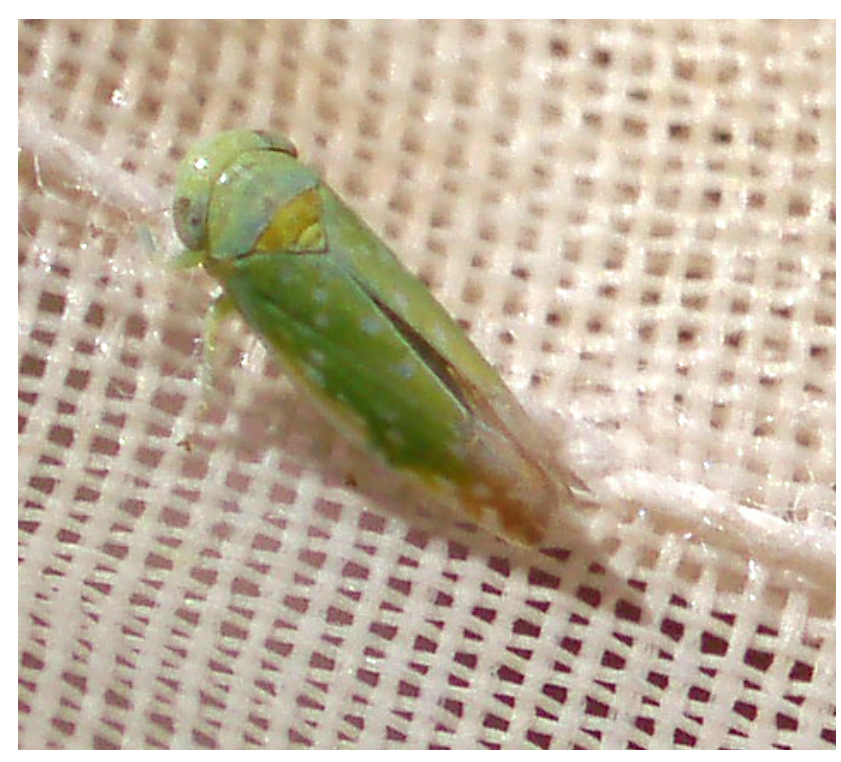

Figure 1. Tamarix spp. leafhoppers [Ciciadellidae: Opsius stactogalus (Fieber)] are host-specific and are cryptically colored, mimicking Tamarix spp. cladophylls.

often detect a gentle rain of leaf hopper honeydew during the summer months. Copious production of honeydew by other tree-dwelling Hemiptera is well documented in other systems [22]. For example, a population of lime aphids was estimated to annually produce up to $800 \mathrm{~g}$ honeydew $/ \mathrm{m}^{-2}$ [23]. The role of honeydew accumulation in the phyllosphere and beneath the tree canopy has been shown to support the development of microbial litter and soil communities, particularly including fungi [18] [24] [25]. Studies involving native, non-invasive species report that honeydew fuels micro-organism metabolism and critically affects above- and below-ground nutrient dynamics [17]. Fungal hyphae also increase on aphid galls when honeydew increases [26], and on soil and leaf surfaces containing honeydew [25] [27]. Honeydew on wheat leaves stimulates the growth of pathogenic filamentous fungi [28], reducing seed germination and establishment. Aphid infestation and honeydew deposition on understory soil surfaces have been associated with reduced plant-available soil nitrogen and aboveground net primary production [25]. Sticky herbivore honeydew is shown to interrupt harvesting processes and support damaging fungal growth, sometimes greatly reducing yield [29]. While the role and distribution of arbuscular mycorrhizae in Arizona riparian zones have received some attention [30], those of non-arbuscular fungi have not, to our knowledge. Better understanding of these complex multi-trophic level interactions, including non-linear responses, may reveal insights into mechanisms of nonnative species invasion success due to suppression of competitor recruitment [31].

We hypothesized that multi-trophic interactions between Tamarix spp., host-specific Opsius, and understory litter fungi inhibit seedling establishment of perennial species beneath the Tamarix spp. canopy (Figure 2). We conducted field surveys to quantify leafhopper abundance and honeydew accrual under individual Tamarix spp. plants across a $1600 \mathrm{~m}$ elevation gradient in Arizona, to relate differences in leafhopper abundance to length of growing season at various elevations. We conducted field and laboratory experiments to determine the influence of synthetic honeydew, Tamarix spp. litter fungi, and their interactions on the mortality and germination success of Tamarix spp., $P$. fremontii, and B. salicina seeds. We addressed the following questions. 1) Do litter fungi differentially colonize Tamarix spp., $P$. fremontii, and B. salicina seeds and seedlings beneath Tamarix spp. canopy, and does the presence of soil moisture increase the proportion of seeds colonized? 2) Does fungal colonization of seeds under Tamarix spp. canopy differentially decrease all three species' seed viability in the field? 3) Does seed or 4) seedling viability decrease in the presence of Tamarix spp. litter, synthetic honeydew, or those factors in combination? 5) Does seedling viability decrease in a dosage-dependent fashion with the application of synthetic honeydew? We recognize that multi-trophic, herbivore-vectored interactions are just one of many species-specific, physical, and plant-initiated processes that may affect understory vegetation development and contribute to the invasion success and stand persistence of Tamarix spp. 


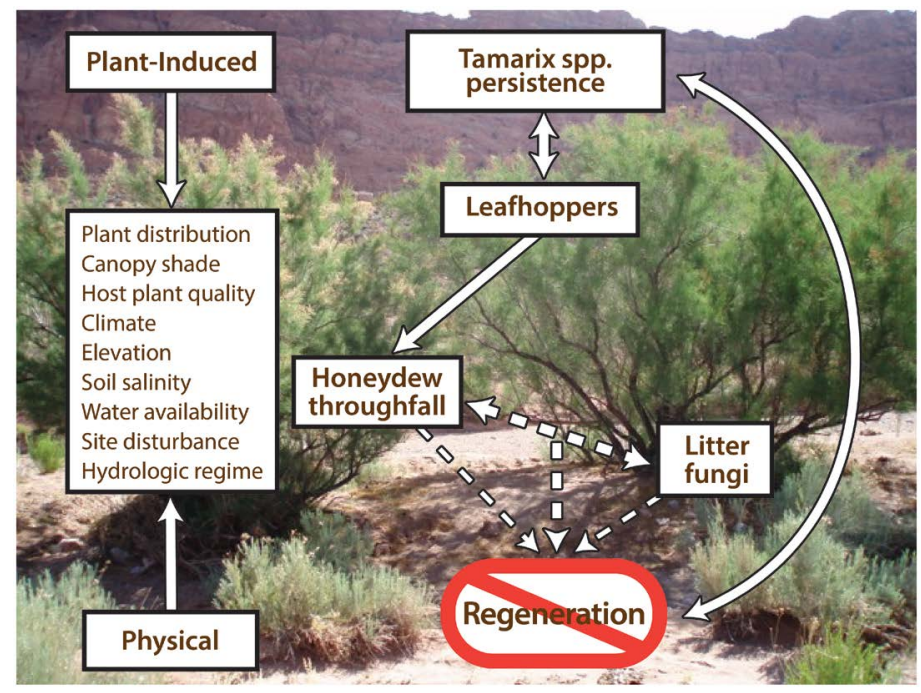

Figure 2. Coneptual diagram of Tamarix spp., Opsius stactogalus leafhopper honeydew production, and soil fungal interactions hypothesized to reduce riparian plant germination and seedling establishment under Tamarix spp. canopies in the lower Colorado River basin.

\section{Materials and Methods}

\subsection{Study Sites}

We conducted seedling surveys and leafhopper monitoring on Tamarix spp. across a $1600 \mathrm{~m}$ elevation gradient at four Arizona field sites: Yuma, Willow Beach, Lees Ferry, and Echo Cliffs (Table 1 and Figure 3). We quantified honeydew throughfall beneath Tamarix spp. canopies at Lees Ferry and Echo Cliffs (Table 2). All sites exist along the dam-regulated Colorado River from northern to southern Arizona except Echo Cliffs, which lies along an intermittent watercourse that receives naturally erratic precipitation-based flood events. Climate at all study sites is arid and continental, and precipitation occurs as winter storms and late summer (July-August) monsoon rains (Table 1). Air temperature and precipitation is generally inversely related to elevation and varies seasonally, with minimum and maximum ranges of $7^{\circ} \mathrm{C}$ to $41^{\circ} \mathrm{C}$ in Yuma, to $-7^{\circ} \mathrm{C}$ to $34^{\circ} \mathrm{C}$ at Echo Cliffs [32]. The year of our field studies (2007) was relatively normal with regard to the range of seasonal temperatures and precipitation.

\subsection{Study Organisms}

We studied Tamarix spp. canopy, Opsius stactogalus leafhopper population dynamics and honeydew production, and soil fungal impacts on seed and seedling survivorship and recruitment in Tamarix spp. and two native perennial, commonly co-occurring phreatophytic plant species: $P$. fremontii and B. salicina. Seeds of each species were collected from 10 or more different plants at multiple sites in 2007. Seed batches were mixed and refrigerated for use in the experiments described below. We related plant responses to Opsius honeydew production and fungal colonization on a seasonally appropriate basis by conducting in situ field experiments at the time each plant species naturally released its seeds.

\subsection{Field Surveys}

To determine the extent of plant recruitment beneath Tamarix spp., we conducted seedling surveys beneath individually marked Tamarix spp. canopies five times at all sites from 31 March 2007 to 29 September 2007 ( $n=$ 80 ). We searched the soil surface beneath each individual Tamarix spp. canopy and recorded the number of seedlings per species.

We quantified Opsius abundance in the field by surveying the same marked Tamarix spp. plants $(n=80$; above) at each of the four sites once every 17 - 21 days through the 2007 growing season (Table 1). We sam- 


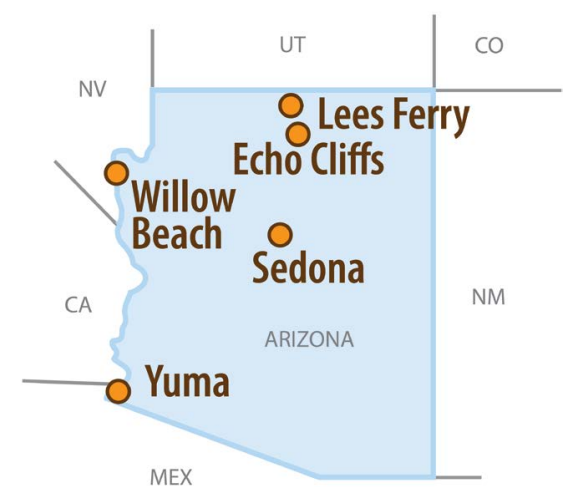

Figure 3. Map of the four study areas in Arizona. Geography and climate data are provided in Table 1 . Sedona (1370 m elevation) was used as a centrally-located outdoor experimental site.

Table 1. Seedling and Opsius stactogalus leafhopper surveys were conducted at four Arizona field sites approximately every 21 days during the 2007 growing season. Growing season and local climate varied by elevation among the field study sites.

\begin{tabular}{|c|c|c|c|c|c|c|c|}
\hline Site & $\begin{array}{l}\text { Elevation } \\
\quad(\mathrm{m})\end{array}$ & $\begin{array}{l}\text { Latitude, } \\
\text { Longitude }\end{array}$ & $\begin{array}{l}\text { No. } \\
\text { Trees }\end{array}$ & $\begin{array}{l}\text { No. Days in } \\
\text { Growing Season }\end{array}$ & Site Description & $\begin{array}{c}\text { Range of Mean } \\
\text { Monthly Air } \\
\text { Temperature }\left({ }^{\circ} \mathrm{C}\right)\end{array}$ & $\begin{array}{l}\text { Mean Annual } \\
\text { Precipitation } \\
\quad(\mathbf{m m})\end{array}$ \\
\hline Yuma & 21 & $\begin{array}{l}\mathrm{N} 32.729^{\circ} \\
\text { W } 114.618^{\circ}\end{array}$ & 29 & 365 & $\begin{array}{l}\text { Colorado River } \\
\text { Strandline }\end{array}$ & 7 to 41 & 76.4 \\
\hline Willow Beach & 200 & $\begin{array}{l}\mathrm{N} 35.870^{\circ} \\
\mathrm{W} 114.660^{\circ}\end{array}$ & 19 & 220 & $\begin{array}{c}\text { Lake Mohave } \\
\text { Reservoir Shoreline }\end{array}$ & 3 to 42 & 153 \\
\hline Lees Ferry & 945 & $\begin{array}{l}\mathrm{N} 36.861^{\circ} \\
\text { W } 111.594^{\circ}\end{array}$ & 20 & 182 & $\begin{array}{l}\text { Mouth of Paria River } \\
\text { at Colorado River }\end{array}$ & -3 to 39 & 155 \\
\hline Echo Cliffs & 1650 & $\begin{array}{l}\mathrm{N} 36.326^{\circ} \\
\mathrm{W} 111.480^{\circ}\end{array}$ & 12 & 148 & Ephemeral Wash & -7 to 34 & 162 \\
\hline
\end{tabular}

Table 2. Cumulative estimated Opsius honeydew accumulation $\left[\mathrm{g} \cdot \mathrm{m}^{-2}(95 \% \mathrm{CI})\right]$ among five 21-day sampling period during the 2007 growing season measured at the Lees Ferry and Echo Cliffs study sites. Honeydew was collected on glass slides beneath individual Tamarix spp. canopies for $24 \mathrm{hr}$, and averaged among trees. Daily accumulation values were multiplied by the number of days in the sampling period (usually 21), and totaled to estimate the annual mean honeydew deposition value $\left(\mathrm{g} \cdot \mathrm{m}^{-2} \cdot \mathrm{yr}^{-1}\right)$.

\begin{tabular}{cccccccc}
\hline N & Site & 25 May 2007 & 9 Jul. 2007 & 28 Jul. 2007 & 21 Aug. 2007 & 30 Sep. 2008 & Total \\
\hline 20 & Lees Ferry & $152.3(81.8)$ & $141.8(69.0)$ & $11.7(5.3)$ & $12.4(11.0)$ & $11.8(14.0)$ & $330.3(180.3)$ \\
12 & Echo Cliffs & $18.2(12.5)$ & $66.5(49.0)$ & $51.5(31.0)$ & $92.7(61.1)$ & $406.3(287.2)$ & $727.0(485.7)$ \\
\hline
\end{tabular}

pled Opsius density on the foliage of each tree using an aerial insect net (ten $2 \mathrm{~m}$ sweeps per tree per visit), recording the number of Opsius captured. After enumeration, all insects were released back onto the host plants.

We monitored honeydew throughfall beneath the canopies of individual Tamarix spp. plants at the Lees Ferry and Echo Cliffs sites through the 2007 growing season (Table 2). We measured honeydew accumulation five times from May to October by placing 12 microscope slides (surface area $/$ tree $=15 \mathrm{~cm}^{2}$ ) on the ground beneath the canopy for a $24 \mathrm{hr}$ sampling period. Slides were boxed and stored at $-4^{\circ} \mathrm{C}$ until processing at the Colorado Plateau Analytical Laboratory on the Northern Arizona University (NAU) campus in Flagstaff. In the laboratory, each slide was rinsed with $80^{\circ} \mathrm{C}$ nanopure water, and filtered (Whatman $\# 390 \mathrm{~mm}$ quantitative paper) into an 85 g glass container. This solution was frozen for $24 \mathrm{hr}$, lyophilized, and the contents were weighed using a microanalytical balance. We quantified the dry mass of honeydew throughfall per sample period, and Opsius abundance (mean number of leafhoppers per 10 aerial net sweeps) at each site across the season, and we also related leafhopper abundance to honeydew accumulation $\left(\mathrm{g} \cdot \mathrm{m}^{-2}\right)$ by averaging across the monitoring period and using rank correlation analysis. All data presented in this manuscript were analyzed in JMP [33]. 


\subsection{Field and Laboratory Experiments}

Question 1: To test whether fungi colonize seeds differentially beneath mature Tamarix spp. canopies, we conducted a field seed bag experiment at Lees Ferry. This test consisted of three individual experiments, each conducted during the period of natural seed release for the three riparian species (P. fremontii from $25 \mathrm{Apr}$. 2007 to 25 May 2007; Tamarix spp. from 27 Jul. 2007 to 26 Aug. 2007; and B. salicina from 2 Nov. 2007 to 4 Dec. 2007). We placed approximately 25 seeds in each of $20-25$ pairs of seed bags $(5 \mathrm{~cm} \times 5 \mathrm{~cm}, 1 \mathrm{~mm}$ nylon mesh $)$ beneath 20 - 25 Tamarix spp. plants (Figure 4). Seed bags were sterilized with a 5\% bleach solution. The nylon bags excluded seed-eating macro-arthropods and mammals, but allowed seeds to be colonized by ambient soil microbes. Seed bags were transported to the field site and placed in pairs under the canopy of mature trees. Each bag was filled with $15 \mathrm{~g}$ of Tamarix spp. litter from the host tree. Bags were stapled shut and buried to a depth of $3 \mathrm{~cm}$ in the litter layer. Individual bags within a pair were placed $1 \mathrm{~m}$ apart. To induce the activity of potential litter organisms, one of the paired bags was treated with $125 \mathrm{ml}$ of nanopure water at the time of burial. Pairs of seed bags were placed at the Lees Ferry site for each of three experiments. After one month, bags were retrieved and the number of seeds with $>50 \%$ of the seed coat colonized by fungi was recorded.

Question 2a: To determine whether seed colonization by Tamarix spp. litter fungi reduced seed viability, seeds were extracted from the bags, sifted from the litter fragments, placed in a growth chambers (Percival, Boone, IA 1-35LL) at the NAU research greenhouse, and then germinated. Seeds from watered vs. not-watered seed bags were placed in separate petri dishes and kept moist under controlled conditions $\left(\mathrm{D} 33^{\circ} \mathrm{C} / \mathrm{N} 18^{\circ} \mathrm{C}, \mathrm{D} 14\right.$ $\mathrm{h} / \mathrm{N} 10 \mathrm{~h}, 25 \% \mathrm{RH})$. The number of seeds colonized by fungi per dish was counted before placement in the growth chamber. A seed was considered colonized if $>50 \%$ of the seed surface was covered in fungal mycelia at 10-power magnification. After one month, the number of viable seeds was counted in each dish. A seed was considered viable if it had imbibed water and radicle emergence exceeded $1 \mathrm{~mm}$.

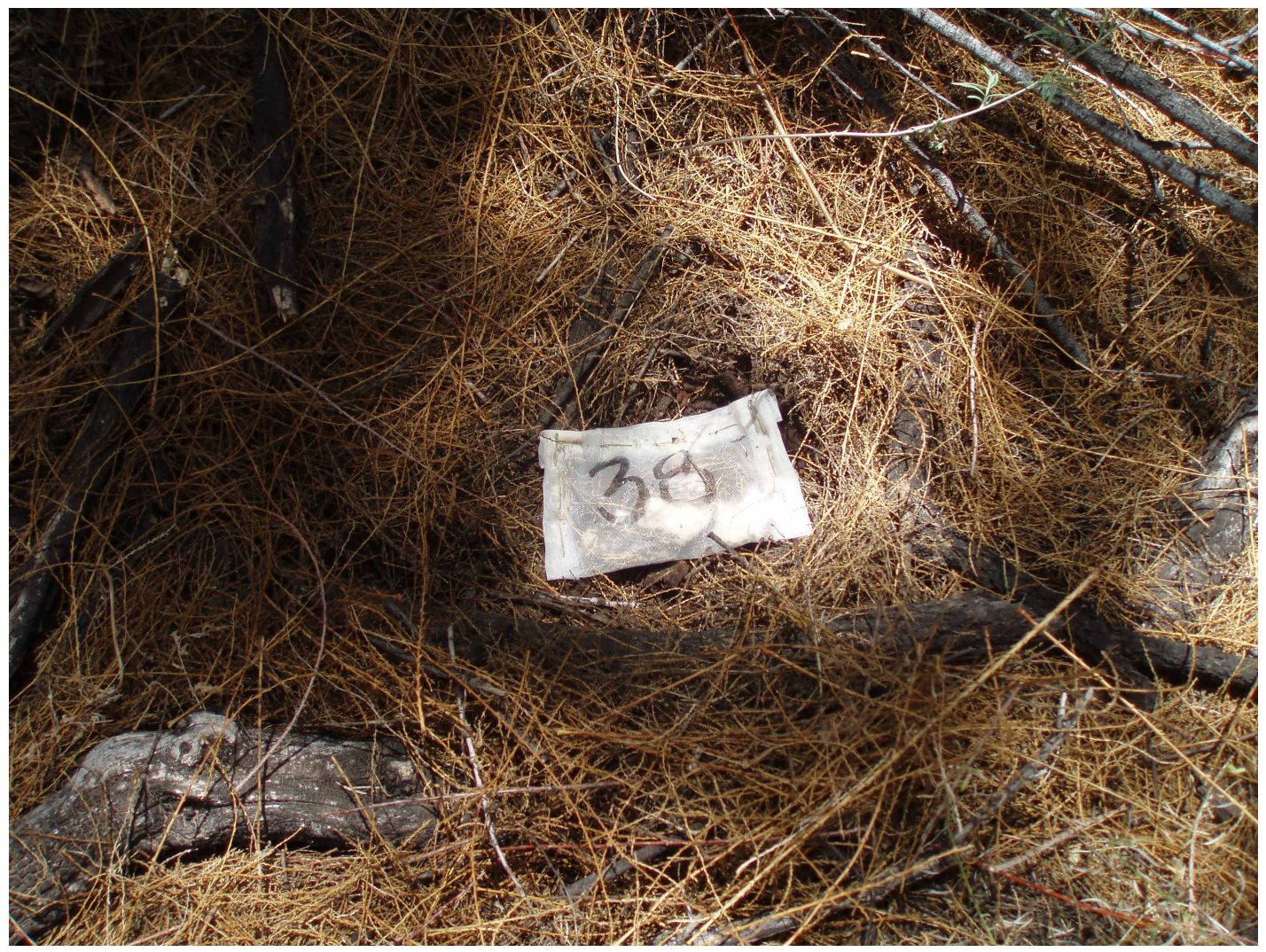

Figure 4. Pairs of experimental mesh bags (one watered, one not watered) were loaded with Tamarix litter and approximately 25 seeds of each of the target riparian plant species, placed into the surface leaf litter beneath Tamarix canopies for natural innoculation with under-canopy fungi, and then tested for germination viability to answer study questions 2.4 .1 and 2.4.2a. 
Because parametric assumptions of normality and equal variances were not met, these data were analyzed using Wilcoxon signed-rank tests for paired data (watered vs. not-watered bags). Other pairwise comparisons between treatments within species and among species within treatments were conducted with Mann-Whitney U tests. We used sequential Bonferroni adjustment of probability values to determine the significance of pairwise comparisons within the experiments [34]. To test for monotonic relationships among these data, we used a Spearman's rank correlation analysis.

Question 2b: Because the previous analysis provided resolution only at the bag level, we conducted an analysis of seed responses to fungal colonization in petri dishes in the laboratory. We placed 20 petri dishes each containing 50 seeds per species for 10 days in growth chambers (same settings as above). All three species' seeds were exposed to four treatments: control (no treatment), addition of $5 \mathrm{~g}$ Tamarix spp. litter, fungicide (Captan Fungicide 50\% WP, Bonham, TX), and fungicide + Tamarix spp. litter. The fungicide and fungicide + litter treatments produced results similar to that of the no treatment controls, and those data are not discussed further. Dishes containing Tamarix spp. litter were kept in a separate growth chamber to prevent fungal propagule transfer between dishes not treated with litter (controls). Dishes were rotated every 2 days to eliminate placement effect within the growth chambers. Seeds were exposed to treatments and potential fungal colonization for 2 days, after which the number of colonized seeds was counted in each dish. Seeds colonized versus not colonized by fungi were separated, placed into individual petri dishes for an 8 day germination trial, and kept moist. At the conclusion of the trial, each seed was inspected for survivorship (alive = green, hypocotyl and radicle emergence). Logistic regression was used to analyze the relationship between seed survivorship (response variable) and fungal colonization status (predictor variable).

Question 3: To determine whether seed viability was reduced in the presence of Tamarix spp. litter, synthetic honeydew or litter + honeydew, we tested the viability of the three species' seeds in the NAU growth chambers (same settings as in question 2.4.2) for one month under four treatments: control (no treatment), Tamarix spp. litter only, $5 \mathrm{ml}$ synthetic honeydew only, and synthetic honeydew + litter. Fifty seeds were placed in a large petri dish $(20$ reps per treatment; $\mathrm{n}=240)$. Dishes were watered every other day and a 3\% (mass $/$ volume; m/v) synthetic honeydew solution was applied to the appropriate dishes, three times over the course of the month. The synthetic honeydew used in this and all experiments consisted of sucrose and melezitose (9:1; 99\% assay, Spectrum Chemical Mfg Corp., Gardena, CA) dissolved in nanopure water to create a 3\% (m/v) solution. Sucrose and melezitose are two of the primary sugars found in naturally-occurring honeydew of related hemipteran species [23] [35].

We tested for differences in seed survivorship using Kruskal-Wallis and Mann-Whitney U tests for means comparisons, with a sequential Bonferroni correction on comparisons within treatments among species, and within species among treatments. We also related the mean percent of seeds colonized per dish and the mean percent of viable seeds per dish using Spearman's rank correlation $\left(\rho_{\mathrm{S}}\right)$ analyses by species with treatments pooled.

Question 4: To examine whether seedling viability decreased in the presence of Tamarix spp. litter, and synthetic honeydew + litter, we performed comparative growth chamber experiments. Seeds of all three species were surface-sown in $8 \times 3 \mathrm{~cm}$ Ray Leach "Conetainers"TM (Stuewe and Sons, Inc., Corvallis, OR SC-10) set into large plastic tubs of shallow water at an outdoor field experimental site in Sedona, Arizona at an elevation of $1370 \mathrm{~m}$. We randomized tub effects by rotating containers between tubs and chambers once per week. Containers were filled with sterilized silty-fine sand and capillary action of the sand drew water into the tubes so that daily watering was not needed. Tubs were cleaned and refilled weekly. Seeds germinated and were weeded to one viable seedling per container after two weeks. The following treatments were applied to approximately 20 seedlings each: control (no treatment), Tamarix spp. litter only, and synthetic honeydew + litter. The experiment was conducted for 30 days, after which seedling survivorship was recorded. These data were analyzed using $X^{2}$ tests both within species among treatments and within treatments among species, and sequential Bonferroni adjustment of probability values was used on comparisons of $P$ values for each plant species test.

Question 5: Lastly, we tested the effect of honeydew concentration on seedling viability, predicting a positive, dosage-dependent relationship between synthetic honeydew concentration and seedling mortality across species. Seeds were surface-sown, weeded and rotated between and within the chambers in the same experimental design as in question 4 (above). We tested seeds and seedlings across multiple concentrations congruent with naturallyderived honeydew $(>0.1 \% \mathrm{~m} / \mathrm{v})$ [36] [37], and we varied honeydew concentration from $0.0001 \%$ to $20 \%$ (m/v). Treatments were applied to batches of approximately 20 germinated seeds each, and included: control (no 
treatment), $0.0001 \%, 0.001 \%, 0.1 \%, 10 \%$, and $20 \%(\mathrm{~m} / \mathrm{v})$. Containers were watered three times and mortality was determined after 30 days. We tested for differences using $X^{2}$ tests both within species among treatments and within treatments among species, and used a sequential Bonferroni adjustment in all tests.

\section{Results}

\subsection{Field Surveys}

We found no seedlings of Tamarix spp., P. fremontii, or B. salicina under Tamarix spp. canopies at any of the four field sites on any sample date. Litter depth beneath Tamarix spp. often exceeded $20 \mathrm{~cm}$. Seedlings of all species were observed in open riparian areas outside of Tamarix spp. canopies at most sites. B. salicina seedlings were rarely observed under Tamarix spp. at other sites along the Colorado River not included in this study, indicating that $B$. salicina occasionally is capable of germinating under Tamarix spp. canopies.

Opsius stactogalus was the only leafhopper species collected on Tamarix spp. during the monitoring effort. These leafhoppers occurred across the entire elevational range studied $(1600 \mathrm{~m})$ and were numerous at all four field sites (Figure 5). Opsius emerged as Tamarix spp. leafed out, and disappeared in the autumn after the first hard frost or when deciduous Tamarix spp. shed its cladophylls. Opsius distribution was consistent between trees within a stand, except for one plant at Willow Beach that consistently supported no leafhoppers. Interestingly, the highest relative mean Opsius abundance within a stand occurred at the highest elevation site, Echo Cliffs. Low elevation sites, such as Yuma and Willow Beach supported lower densities of Opsius, but for a longer duration through the 2007 growing season.

Honeydew accumulated abundantly on the litter/soil surface beneath Tamarix spp. at both field sample sites (Lees Ferry and Echo Cliffs). Opsius abundance and honeydew throughfall dry mass $\left(\mathrm{g} \cdot \mathrm{m}^{-2}\right)$ were positively related at each sample date, except early July ( 9 Jul. 2007) when rain splash from monsoon storms likely diluted honeydew samples collected (25 May 2007: $\rho_{\mathrm{S}}=0.55, P=0.0012$; 9 Jul. 2007: $\rho_{\mathrm{S}}=0.28, P=0.11 ; 28 \mathrm{Jul}$. 2007: $\rho_{\mathrm{S}}=0.51, P=0.0031 ; 21$ Aug. 2007: $\rho_{\mathrm{S}}=0.52, P=0.0026 ; 30$ Sept. 2007: $\rho_{\mathrm{S}}=0.69, P=<0.0001$; Figure 6(a) and Figure 6(b)). Overall, we found that honeydew accumulation beneath Tamarix spp. canopy over 30 days (approximately one generation of leafhoppers) varied from 0.0008 to $0.01 \mathrm{~g} \cdot \mathrm{cm}^{-2}\left(0.3\right.$ to $\left.3.3 \mathrm{~g} \cdot \mathrm{m}^{-2} \cdot \mathrm{day}^{-1}\right)$. Discrepancies between Opsius abundance and honeydew production in early summer at Lees Ferry and late summer at Echo Cliffs (Figure 6(a)) were due to varying proportions of larval versus adult leafhoppers (i.e., a higher proportion of adult, rather than larval, Opsius during a sampling period likely resulted in greater honeydew production). High performance liquid chromatography (HPLC) analyses confirmed that glucose, fructose, sucrose and melezitose are the most abundant sugars in Opsius honeydew.

\subsection{Field and Laboratory Experiments}

Question 1: Two lines of evidence indicate that Tamarix spp. litter fungi readily colonized all three species seeds under Tamarix spp. canopies. First, under the not-watered treatment, all three species seeds were colo-

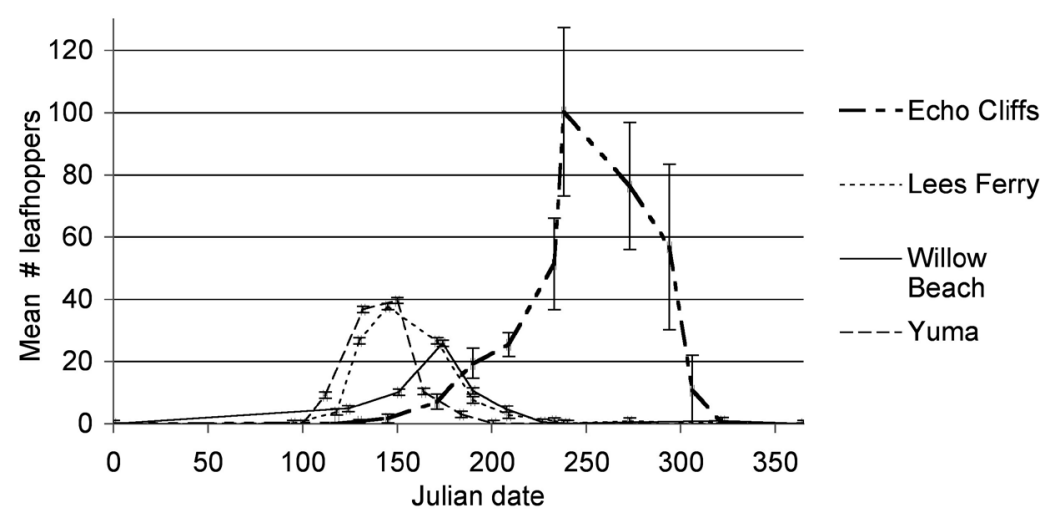

Figure 5. Mean number of Opsius stactogalus 10 sweeps by Julian day at each of four Arizona field sites through the 2007 growing season. Site locations are described in Table 1. Error bars are $\pm 1 \mathrm{SE}$. 


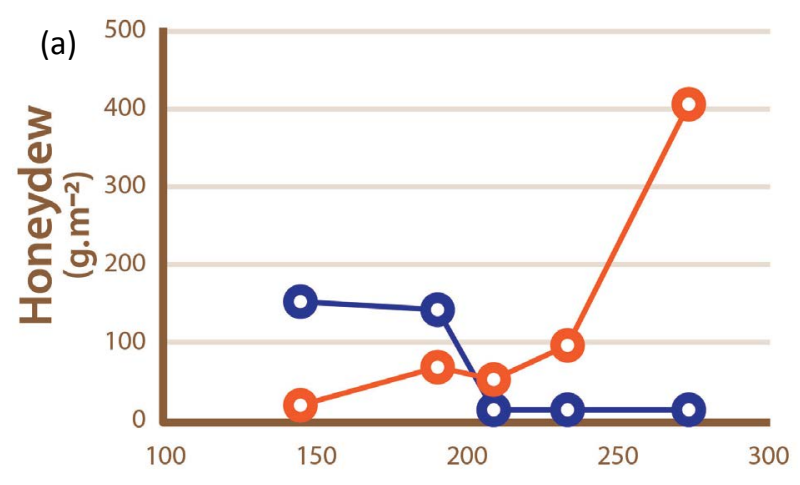

(b)

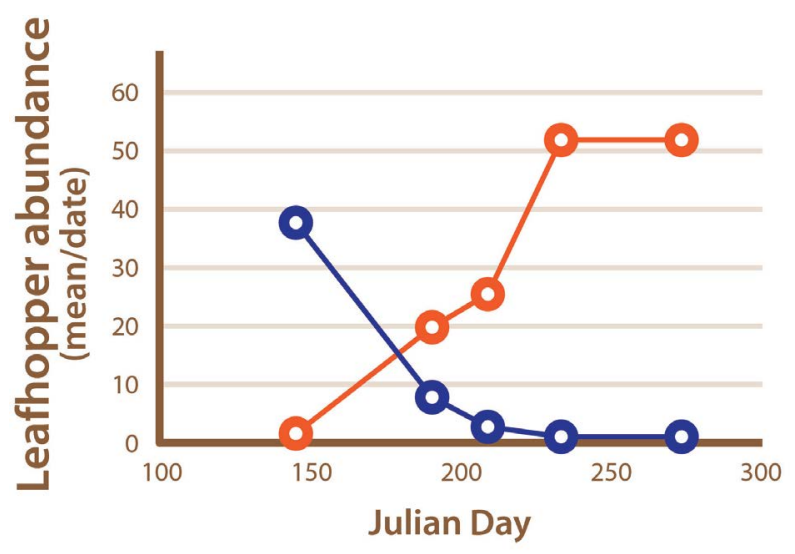

\section{-0 Lees Ferry 00 Echo Cliffs}

Figure 6. (a) Honeydew $\left(\mathrm{g} \cdot \mathrm{m}^{-2}\right)$ production per month, and (b) mean Opsius leafhopper/10 sweeps (n-32 trees) by Julian day in 2007 at two field sites: Lees Ferry (dark blue circles) and Echo Cliffs (light red circles).

nized by fungi (Figure 7(a)). Bags with Tamarix spp. exhibited a particularly high mean percentage of seeds colonized by litter fungi. Watered seed bags exhibited an even higher mean percent of fungal colonization than those that were not-watered, demonstrating that moisture promoted fungal colonization. Tamarix spp. seeds were the only species exposed to monsoon rains in the field; therefore, the high colonization rates and associated low viability may be due to increased ambient moisture during that season. P. fremontii watered seed bags had 5 -fold greater mean percent of fungal colonization than the not-watered bags $\left(\mathrm{z}_{20}=105 ; P<0.0001\right)$. Watered bags with Tamarix spp. seeds had $10 \%$ greater mean percent of seeds colonized than the not-watered bags $\left(\mathrm{z}_{24}=\right.$ $105 ; P<0.0001)$. Watered seed bags with $B$. salicina seeds had 10 -fold greater mean percent of seeds colonized than not-watered bags $\left(\mathrm{z}_{24}=162.5 ; P<0.0001\right)$. In not-watered treatments, the mean percent of bag scolonized by fungi among ranged from 5\% - 81\% among all three plant species, while that for watered bags ranged from $60 \%$ 92\%. Watered Tamarix spp. seeds had 35\% higher susceptibility to litter fungi than did P. fremontii, and 19\% higher than B. salicina. Not-watered Tamarix spp. seeds had $87 \%$ higher mean percent off ungal colonization than $\operatorname{did} P$. fremontii, and a $94 \%$ higher rate than did B. salicina.

Second, all pairwise comparisons of mean percent seed colonization within treatments among plant species were significant $(P<0.05)$, except those of $P$. fremontii-B. salicina in the watered and not-watered treatments (Figure 7(a)). These data indicate that although the mean percent of seeds colonized was greater in moist soil conditions for all species, Tamarix spp. seeds were particularly vulnerable to fungal colonization, regardless of treatment (Figure 7(a) and Figure 8). Field experimentation across years is needed to determine the extent to which annual weather variability influences these patterns. 


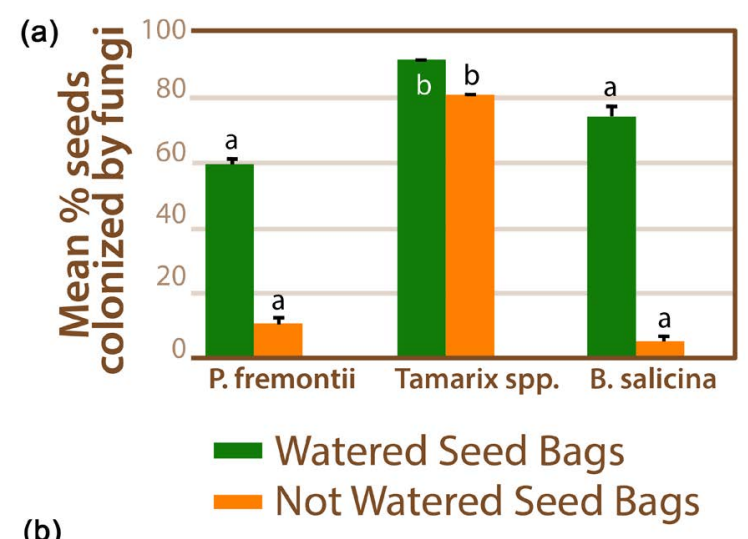

(b)

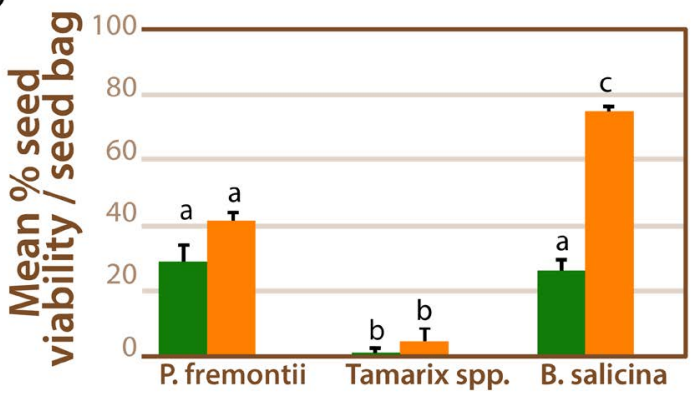

Figure 7. Lees Ferry seed bag tests: (a) mean percent fungal infestation of mesh seed bags for three plant species seeds subjected to Tamarix spp. litter, in watered versus not-watered treatments, and (b) viability of seeds within seed bags in watered versus not-watered treatments. Different letters indicate significant differences among plant species between treatments using Mann-Whitney U tests at $P<0.05$. Between treatment results were significant for each species. Error bars are $+1 \mathrm{SE}$.

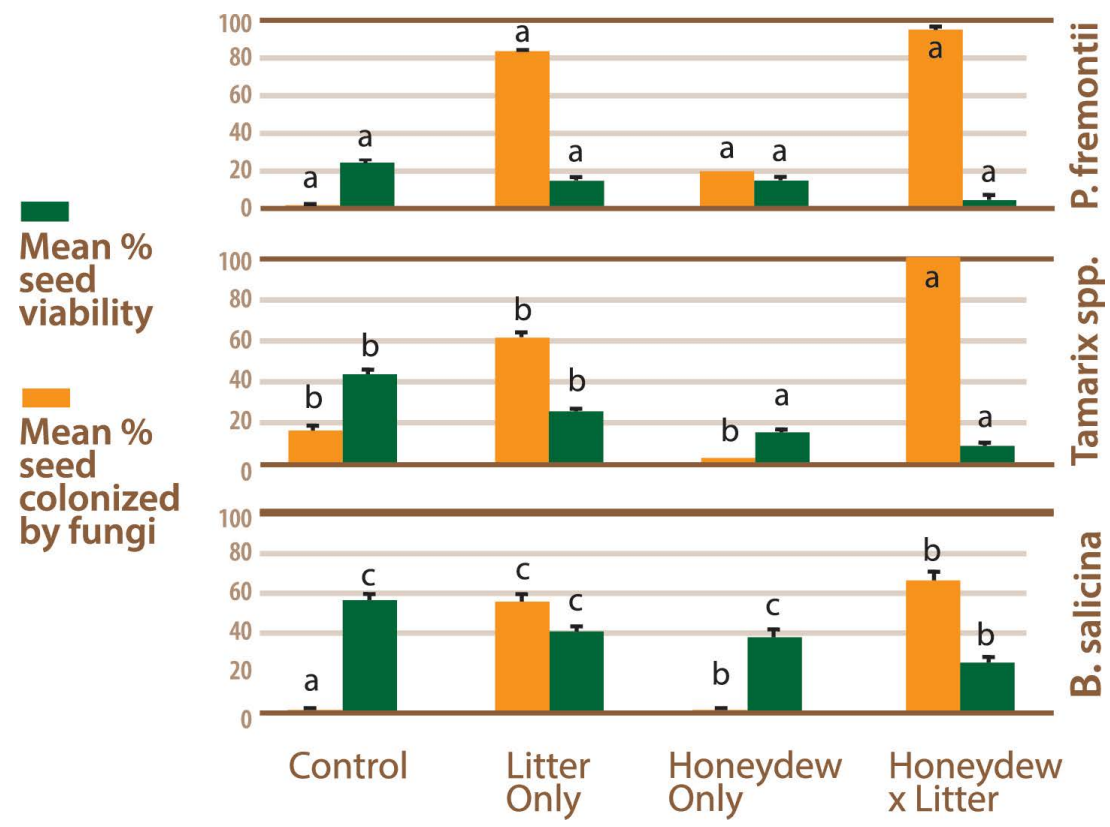

Figure 8. Growth chamber experimental tests of the effects of synthetic honeydew and Tamarix spp. litter on percent seed germination of $P$. fremontii, Tamarix spp., and B. salicina seeds that were colonized by litter fungi, and the mean percent of viable seeds under four treatments: control, Tamarix spp. litter only, synthetic honeydew only, and synthetic honeydew + Tamarix spp. litter. Different letters indicate significant differences among species within treatments using Mann-Whitney $\mathrm{U}$ tests at $P<0.05$. Among treatment tests were significant for all species. Error bars are $+1 \mathrm{SE}$. 
Question 2a: We found that fungal-colonized seeds were associated with reduced seed viability at both the whole bag level in the field (Figure 7(b)) and in laboratory petri dish experiments (Figure 8), with differences among species between treatments. P. fremontii seeds in the watered treatment had $12 \%$ lower viability than those not-watered $\left(\mathrm{z}_{20}=-105.5 ; P<0.0001\right.$; Figure 7(b)), with a mean germination rate of $81 \%$ for seeds not subjected to Tamarix spp. litter. Tamarix spp. seeds in the watered treatment sustained a 4-fold reduction in viability compared with those that were not watered $\left(\mathrm{z}_{24}=-115.5 ; P<0.0001\right.$; Figure $\left.7(\mathrm{~b})\right)$. B. salicina seeds in the watered treatment had 2.8-fold lower viability than those not-watered $\left(\mathrm{z}_{24}=-160.5 ; P<0.0001\right)$, with a mean germination rate of $27 \%$. All pairwise comparisons between species within the watered and not-watered treatments were significant $(P<0.05)$, except for $P$. fremontii and B. salicina in the watered treatment. As in the whole-bag colonization analysis, Tamarix spp. exhibited significantly lower seed viability than did the two native species, under both the watered and not-watered treatments. Thus, the native phreatophytes exhibited lower seed viability due to fungal colonization under conditions of high soil moisture availability, while Tamarix spp. seeds exhibited far greater susceptibility to fungal colonization overall compared to either of the native species and regardless of the moisture regime.

Fungal colonization reduced seed viability for all three species (Figure 7(b) and Figure 8). Each Spearman's correlation analysis within species was significant $\left(P\right.$. fremontii $\rho_{\mathrm{S}}=-0.71, P<0.0001$; Tamarix spp. $\rho_{\mathrm{S}}=-0.33$, $P<0.02 ;$ B. salicina $\rho_{\mathrm{S}}=-0.49, P<0.001$ ), demonstrating a negative relationship between fungal colonization susceptibility and seed viability.

Question 2b: To test for treatment dish effects on seed viability, we ran the logistic regression with two predictors [colonization status and replicate as blocking variables (replicates $=20$ petri dishes containing $\sim 50$ seeds/ species/treatment)]. We found that replicate and species did not differ from one another and consequently we pooled all data intoa single analysis. The overall logistic regression revealed that fungal colonization increased the likelihood of mortality for all species' seeds 40 -fold over controls $(z=426.45, P<0.0001 ; \beta=-1.68, \mathrm{SE}=$ 0.08 , odds ratio $=29.28$ ). Thus, fungal colonization was a strong predictor of seed mortality.

Question 3: Two lines of evidence indicate that seed viability of all three species decreased in response to litter addition (i.e., fungal colonization) and synthetic honeydew treatments in growth chamber trials. First, the highest germination success occurred among the controls, with progressively reduced germination among $\mathrm{Ta}$ marix spp. as litter, honeydew and combined treatments were added (Figure 8). All pairwise comparisons within species among treatments were significant $(P<0.0001)$, with the exception of the litter only - honeydew treatment for Tamarix spp. Single factor responses decreased survivorship but not as severely as did the combination of honeydew + litter ( $P$. fremontii five-fold lower, Tamarix spp. seven-fold lower, B. salicina two-fold lower). Tamarix spp. and $P$. fremontii demonstrated greater vulnerability to the honeydew + litter treatment than did B. salicina (Figure 8).

Second, Spearman's rank correlation analysis by species with treatments pooled, demonstrated a negative association between the mean percent of colonized seeds and mean percent of viable seeds. Each correlation by plant species was significant $\left(P\right.$. fremontii $\rho_{\mathrm{S}}=-0.65, P<0.0001$; Tamarix spp. $\rho_{\mathrm{S}}=-0.40, P<0.0002 ; B$. salicina $\rho_{\mathrm{S}}=-0.60, P<0.0001$ ), again demonstrating a negative relationship between fungal colonization and seed survivorship.

Question 4: Seedling viability decreased in the presence of Tamarix spp. litter and synthetic honeydew. Nine $X^{2}$ comparisons were conducted within species between treatments and within treatments between species (Figure 9). P. fremontii seedling viability in the litter-only addition treatment was less than half that of the control $\left(X^{2}=6.7, d f=1, P=0.0096\right)$ and the honeydew + litter treatment was 7.5 -fold lower than that of the control $\left(X^{2}=13.5, d f=1, P=0.0002\right)$. In comparison with controls, Tamarix spp. seedling viability under the litter only treatment was reduced by one quarter, and by one third under the honeydew + litter treatment $\left(X^{2}=6.9, d f=1, P\right.$ $=0.0083$ ). All species' seedlings were more resistant to Tamarix spp. litter fungi and honeydew inputs than were their seeds, and B. salicina seedlings demonstrated no differential response to treatments (Figure 9).

Question 5: As predicted, seedling viability was inversely related to synthetic honeydew concentration. We found that seedling viability differed among the six synthetic honeydew concentrations for each species $(P$. fremontii $X^{2}=35.84, d f=5, P<0.0001$; Tamarix spp. $X^{2}=83.39, d f=5, P<0001 ; B$. salicina $X^{2}=83.04, d f=5$, $P<0.0001$; Figure 10). Multiple pairwise $X^{2}$ tests within species among treatments revealed significantly decreased seedling viability above honeydew concentrations of $10 \%(\mathrm{~m} / \mathrm{v})$ for each species. Multiple pairwise $X^{2}$ tests within treatments among species revealed that the only significant differences existed at $10 \%(\mathrm{~m} / \mathrm{v})$ or greater concentrations $\left(X^{2}=2.77, d f=5, P<0.0011\right)$, where $P$. fremontii seedling viability was significantly 


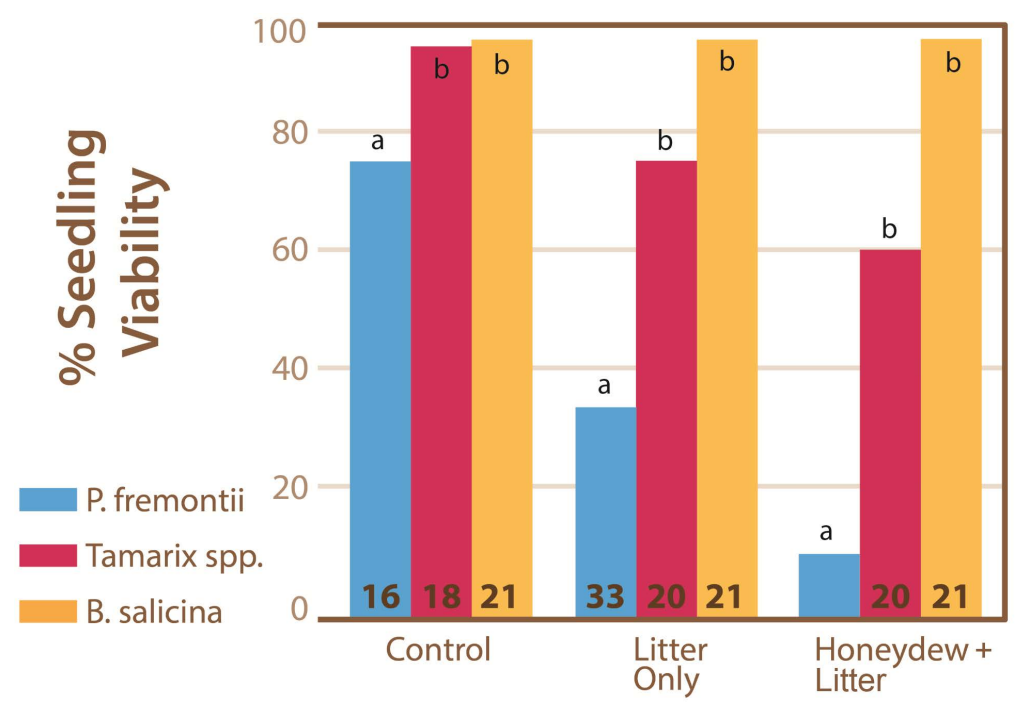

Figure 9. Growth chamber experimental tests on the effects of synthetic honeydew and Tamarix spp. litter on seedling survivorship, showing mean percent of viable seedlings of $P$. fremontii, Tamarix spp., and $B$. salicina under three treatments (control, Tamarix spp. litter only, and synthetic honeydew + litter). Numbers represent sample sizes, and different letters indicate significant differences among species within treatments using $X^{2}$ tests at $P<0.05$. Among treatment tests were significant for all species.

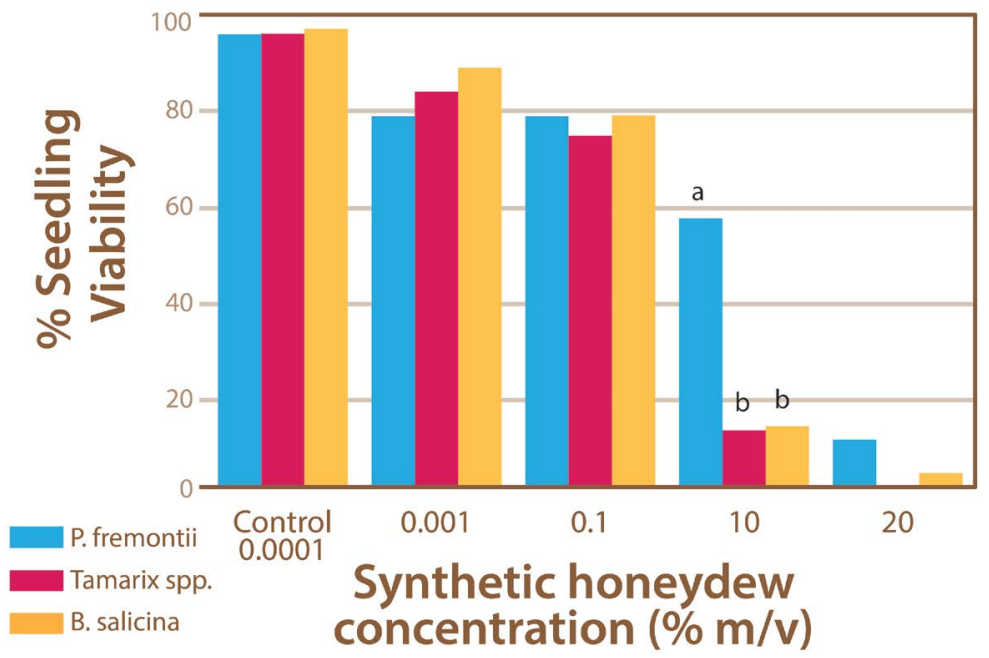

Figure 10. Growth chamber experimental tests of the dosage-dependent impacts of synthetic honeydew on seedling survivorship. Percent seedling viability of $P$. fremontii, Tamarix spp., and $B$. salicina among six synthetic honeydew concentrations. Different letters indicate significant differences within treatments among species using $X^{2}$ tests at $P<0.05$ (significant differences only apply to the $10 \% \mathrm{~m} / \mathrm{v}$ treatment).

higher than those of Tamarix spp. or B. salicina. Thus, dosage-dependent impacts of synthetic honeydew on seedling mortality were apparent at the two highest concentrations applied. However, we could not discern whether this increased mortality was due to increased osmotic stress, a physical barrier to growth, or to interactive or other causes.

\section{Discussion}

\subsection{Interactions among Trophically-Linked Nonnative Species}

In this study, we describe a previously unrecognized trophic interaction among a common and widespread nonnative host plant, its abundant and host-specific nonnative leafhopper herbivore, and an under-canopy litter fun- 
gal assemblage of unknown nativity (Figure 2). Collectively, this honeydew-mediated interaction may greatly reduce the viability of seeds and seedlings beneath the nonnative host plantcanopy. Limitation of understory recruitment may increase Tamarix spp. individual and stand fitness by reducing colonization of potential competitors, particularly including their own progeny. This mechanism may be, in part, responsible for the long-term persistence of dense, monospecific stands of Tamarix spp. throughout the southwestern U.S. [38]. Several consequences emerge from these interactions that affect riparian ecosystem development across elevation in the western U.S.

\subsection{Opsius Honeydew Ecology}

Our study is the first documentation of variation in $O$. stactogalus distribution, density and phenology across elevation, and is the first study of the role of cicadellid honeydew in relation to Tamarix spp. ecology and recruitment dynamics. Artificial honeydew constituents were similar to natural leafhopper honeydew, and the amount applied in our experimental treatments $\left(0.007 \mathrm{~g} \cdot \mathrm{cm}^{-2}\right)$ was conservative within the range of honeydew accrual rates measured at our study sites for the experimental period $\left(0.3\right.$ to $\left.3.3 \mathrm{~g} \cdot \mathrm{m}^{-2} \cdot \mathrm{day}^{-1}\right)$. Due to the potential for honeydew accrual beneath Tamarix spp. canopy across years, particularly in more arid, lower elevation, highly regulated riparian zones, our experimental applications of synthetic honeydew likely underestimate the strength of Opsius honeydew-driven impacts on understory germination and seedling establishment.

The processes through which honeydew limits plant recruitment remains to be explored. Physical or osmotic barriers, such as increased hydrophobicity of seed coats or soils, altered nutrient dynamics, or other biotic and abiotic factors have been described in other ecosystems, and the effectiveness of those mechanisms likely co-varies with environmental conditions, such as water table depth, soil texture, disturbance history, channel geomorphology, and microsite moisture availability. When honeydew concentrations are high, seeds could be physically constrained from expansion by sticky honeydew. When ambient moisture is more abundant and the honeydew concentration is diluted (e.g., during the summer monsoonal rains in the southwestern U.S.), honeydew impacts may be reduced, or osmotic factors or honeydew-derived nutrients may increase the metabolic activity of the fungal assemblage, reducing seed survivorship and potential recruitment. Further studies are needed to determine the extent to which honeydew inputs accrue across years, potentially increasing legacy impacts on recruitment beneath Tamarix spp. canopies.

\subsection{Fungal Ecology}

The shady, more moist Tamarix spp. understory soils in many southwestern riparian woodlands are ideal habitat for fungal survival, spore germination, sporulation, and host colonization. The occurrence and severity of fungal inoculation in Tamarix spp. litter depends on humidity, soil moisture, temperature, light, the density of seeds and/or seedlings present, and the composition of the fungal assemblage. These factors are expected to be less influential in open areas between Tamarix spp. plants, where light intensity is higher and there is less organic matter. In the still-unexplored realm of Tamarix spp. understory fungal taxonomic composition, generalists as well as specialist fungi may co-occur, with some predatory and some non-influential taxa [39]. The litter fungi in this study were not identified, but the mycelia examined revealed cell division characteristics of Ascomycota or Basidiomycota. Seeds collected directly from Tamarix spp. inflorescences also commonly develop heavy fungal infestation, resulting in seed mortality. Such infection may be vectored by the hundreds of generalist pollinating Hymenoptera and Diptera that attend flowering Tamarix spp. [19] [40], raising questions about the extent of pollinator dispersal of seed-consuming fungi among flowering plants. Further studies are needed to identify Tamarix spp. soil fungi, their distribution, nativity, and prevalence in riparian habitats.

\subsection{Riparian Ecosystem Effects}

Despite much research into invasion ecology, the mechanisms supporting nonnative invasions often are poorly understood [20] [41]. Invasion success has traditionally been related to neutral or negative predation or competition impacts on native assemblages [42], but in some cases positive interactions among invading nonnative species result in amplified facilitation of invasion or persistence, and may become key drivers in the population dynamics of numerous native and exotic species [43]-[45]. Tamarix spp. has generally not been considered to produce all elopathic secondary compounds [21], but the interactions we describe here suggest positive feedback 
that promotes the persistence of Tamarix spp. individuals and monocultural stands through herbivore- and soil-fungal-driven inhibition of both conspecific and heterospecific plant species germination and survival. The greatest impacts we detected occurred among combined treatments of honeydew and Tamarix spp. litter. Improved understanding of the role of multi-trophic impacts on non-native plant understories may help predict invasion success [43].

We also report differences in the extent of impact among three common riparian southwestern phreatophyte species. Tamarix spp. and $P$. fremontii seeds were similarly affected by Tamarix spp. litter fungi and honeydew and, in combination, those two treatments further reduced seed and seedling survivorship. In contrast, $B$. salici$n a$ was generally more resistant to the treatments and their combinations. In four of five experiments, $B$. salicina seed and seedling survivorship exceeded those of the two other plant species. B. salicina is as abundant in southwestern riparian habitats as $P$. fremontii, commonly co-occurring at the riverside periphery of Tamarix spp. and Populus stands. But unlike the other two species, B. salicina seeds are released in autumn and its seed longevity exceeds one year (L. Stevens, unpublished data), allowing interannual accumulation in the riparian seed reservoir. Populus and Salix (willow) species have been the focus of much southwestern riparian research as primary colonizers on flood-deposited fluvial sediments. However, based on its greater relative abundance in recent decades in the Colorado River basin, B. salicina appears to be better adapted to opportunistic establishment than P. fremontii [8] [46]. For example, following record post-dam flooding of the Colorado River in Grand Canyon from 1983-1986, extensive germination was reported for Baccharis spp. and Tamarix spp., but not of Salicaceae [47]. B. salicina is relatively short-lived, and as a shrub does not produce the complex habitat structure provided by tree Salicaceae. We postulate that B. salicina will succeed Tamarix spp. along riparian corridors at low-middle elevations as biological control by Diorhabda (Chrysomelidae) leaf beetles reduces Tamarix domination [13]. Further research into the natural history and ecology of B. salicina is needed to clarify autecological and synecological factors influencing its success in southwestern regulated and unregulated river riparian zones.

The multi-trophic impacts on phreatophyte recruitment under Tamarix spp. canopies described in this study do not constitute a full demonstration of causality: in particular, field inoculation trials are needed to better understand the ecological roles of Tamarix spp. litter fungi. However, our community-level approach highlights new mechanisms influencing under-canopy recruitment in Tamarix-invaded ecosystems, and raises questions as to the role of those processes in Tamarix spp. persistence. Many well-studied physical and biological processes contribute to Tamarix spp. persistence in southwestern riparian ecosystems, including salt-, drought- and shadetolerance, vigorous resprouting after fire and rapid regrowth after burial under flood-deposited sediments [48]. While it is generally believed that salinity and shading preclude riparian species from germinating beneath $T a$ marix spp. canopies, some research shows little to no effect of those levels of salinity on P. fremontii seed and seedling mortality in lab or field experiments [49]. Additionally, large-seeded native species, such box elder (Acer negundo), mesquite (Prosopis spp.), and non-native Russian olive (Elaeagnus angustifolia) have the ability to establish under dense Tamarix spp. canopies [3] [41] [50] [47]. Therefore, a combination of physical factors and life history traits among native and nonnative plant species interactively influence Tamarix spp. and other phreatophyte species survival and persistence. To that list of factors, our research adds multi-trophic interactions linking plants, herbivores and fungal influences on understory germination and establishment dynamics in riparian ecosystems.

\subsection{An Evolutionary Interaction?}

The multi-trophic suppression of riparian plant recruitment described here may result from simple physical processes or, in part, from a more complex, evolved strategy. Tamarix spp. escaped nearly all of at least 240 invertebrate herbivore enemies when it arrived in the New World [19]. Similarly, Opsius stactogalus followed its host plant to the New World, escaping most of its parasites and predators [16] [19] [51]. Enemy escape may have intensified trophic linkages between the host plant and its herbivore in the New World, but it is unknown if the interactions described here occur in the native Old World range of Tamarix, where the parental species of Tamarix are separated. There, enemies of both the host plant and herbivore abound and the densities of both species may be lower. The status, distribution and nativity of the as-yet-poorly defined Tamarix under-canopy fungal assemblage requires further investigation, as its ecological impacts likely vary in relation to aridity. Determination of the extent to which these interactions are evolved, rather than simple, physical consequences of co-occurrence, will require similar and comparative measurements and experiments in the native and New World ranges of the 
species involved, as well as among other riparian plant assemblages.

\section{Management Implications}

Rehabilitation and restoration of riparian ecosystems have become a dominant theme in southwestern U.S. river management. Extensive monocultural stands of Tamarix spp. are being removed by mechanical, chemical, and biological control methods at great cost. However, revegetation efforts may be compromised by the effects of honeydew and litter fungi in soils. Our research informs riparian ecosystem rehabilitation project managers about potential honeydew-soil fungi influences. Riparian revegetation plans that incorporate more resistant species, such as shrubby Baccharis, may have higher potential for success, but at the expense of vegetation structural complexity.

Biological control of tamarisk was initiated in the Southwest with the release of the tamarisk leaf beetle (Chrysomelidae: Diorhabda spp.), initiating a broad wave of Tamarix spp. defoliation and gradual mortality from Utah southward to northern Arizona [13] [52]. The introduction of this nonnative beetle is presently eliminating Tamarix spp., Opsius, and avian habitat and food resources [15] [19]. Diorhabda may briefly replace some of those lost riparian food resources, but it eliminates Tamarix spp. cover too quickly for native woody phreatophytes to recolonize. Tamarix spp. is likely to decrease substantially in the Southwest, and the loss of the multi-trophic controls on riparian plant recruitment beneath Tamarix spp. canopies will allow different native and nonnative riparian plant assemblages to develop on new, but as yet unknown successional trajectories.

\section{Acknowledgements}

This research was conducted in partial fulfillment of Ms. Siemion's Northern Arizona University (NAU) Masters of Science degree, and we thank NAU for supporting our work. Funding for this research was provided by the USDA NRI Biology of Weedy and Invasive Plants program, grant \# 2005-35320-16327, and we thank Peter Weisberg of the University of Nevada at Reno and Kelly Burke of Grand Canyon Wildlands Council, Inc. in Flagstaff, Arizona for their administrative support for this project. We thank the United States National Park Service for permission to work along the Colorado River at Lees Ferry and at Willow Beach, and we thank Fred Phillips Consulting for facilitating our work at the East Wetlands in Yuma, Arizona. The Museum of Northern Arizona supports Dr. Stevens' research and houses our specimens. We are grateful to Blanche LaSalle, Karen Huerta and Kim Whitley for enthusiastic assistance with field data collection, and Dr. Roy St. Laurent at NAU for statistical consultation. Loren Haury graciously provided outdoor research space at his farm in Sedona, Arizona. We thank Ben and Jaina Moan (Colorado Plateau Analytical Lab-NAU), Brad Blake, and Phil Patterson (NAU research greenhouse) for technical support and laboratory space. Earlier versions of this manuscript benefitted greatly from reviews and conversations with Thomas Whitham and Catherine Gehring. Mary Williams provided expert graphics support, and we thank an anonymous reviewer and the AE editor for productive comments on this paper.

\section{References}

[1] Wilson, E.O. (1997) Strangers in Paradise. Island Press, Washington DC.

[2] Gaskin, J. and Schaal, B. (2002) Hybrid Tamarix Widespread in U.S. Invasion and Undetected in Native Asian Range. Proceedings of the National Academy of Sciences of the United States of America, 99, 11256-11259. http://dx.doi.org/10.1073/pnas.132403299

[3] Dewine, J. and Cooper, D. (2008) Canopy Shade and the Successional Replacement of Tamarisk by Native Box Elder. Journal of Applied Ecology, 45, 505-514. http://dx.doi.org/10.1111/j.1365-2664.2007.01440.x

[4] Webb, R., Leake, A.S. and Turner, R.M. (2007) The Ribbon of Green: Change in Riparian Vegetation in the Southwestern United States. The University of Arizona Press, Tucson.

[5] Robinson, T. (1965) Introduction, Spread and Aerial Extent of Saltcedar (Tamarix) in the Western States. United States Geological Survey Professional Paper 491-A. USA Geological Survey, Reston.

[6] Carothers, S.W., Johnson, R.R. and Aitchison, S.W. (1974) Population Structure and Social Organization of Southwestern Riparian Birds. American Zoologist, 14, 97-108.

[7] Mahoney, J. and Rood, S. (1998) Streamflow Requirements for Cottonwood Seedling Recruitment—An Integrative Model. Wetlands, 18, 634-645. http://dx.doi.org/10.1007/BF03161678 
[8] Grand Canyon Wildlands Council (2005) Glen and Grand Canyon Riparian Restoration Project: Final Report for Arizona Water Protection Fund. Contract \# 99-075WPF, Phoenix.

[9] Everitt, B. (1980) Ecology of Saltcedar-A Plea for Research. Environmental Geology, 3, 77-84. http://dx.doi.org/10.1007/BF02473474

[10] Turner, R. and Karpiscak, M. (1980) Recent Vegetation Changes along the Colorado River between Glen Canyon Dam and Lake Mead, Arizona. USGS Professional Paper 1132.

[11] Pataki, D., Bush, S.E., Gardner, P., Solomon, D.K. and Ehleringer, J.R. (2005) Ecohydrology in a Colorado River Riparian Forest: Implications for the Declines of Populus fremontii. Ecological Applications, 15, 1009-1018. http://dx.doi.org/10.1890/04-1272

[12] Rood, S. and Mahoney, J. (1990) Collapse of Riparian Poplar Forests Downstream from Dams in Western Prairies: Probable Causes and Prospects for Mitigation. Environmental Management, 14, 451-464. http://dx.doi.org/10.1007/BF02394134

[13] Hudgeons, J.L., Knutson, A.E., Heinz, K.M., DeLoach, C.J., Dudley, T.L., Pattison, R.R. and Kiniry, J.R. (2007) Defoliation by Introduced Diorhabda elongata Leaf Beetles (Coleoptera: Chrysomelidae) Reduces Carbohydrate Reserves and Regrowth of Tamarix (Tamaricaceae). Biological Control, 43, 213-221. http://dx.doi.org/10.1016/j.biocontrol.2007.07.012

[14] Harding, L. (1930) The Biology of Opsius stactogalus Fieber (Homoptera: Cicadellidae). Journal of the Kansas Entomological Society, 3, 7-22.

[15] Yard, H., Van Riper III, C., Brown, B.T. and Kearsley, M.J. (2004) Diets of Insectivorous Birds along the Colorado River in Grand Canyon, Arizona. The Condor, 106, 106-115. http://dx.doi.org/10.1650/7242

[16] Wiesenborn, W. (2005) Biomass of Arthropod Trophic Levels on Tamarix ramosissima (Tamaricaceae) Branches. Environmental Entomology, 34, 656-663. http://dx.doi.org/10.1603/0046-225X-34.3.656

[17] Stadler, B. and Michalzik, B. (1998) Linking Aphid Honeydew, Throughfall, and Forest Floor Solution Chemistry of Norway Spruce. Ecology Letters, 1, 13-16. http://dx.doi.org/10.1046/j.1461-0248.1998.00006.x

[18] Stadler, B. and Müller, T. (1996) Aphid Honeydew and Its Effect on the Phyllosphere Microflora of Picea abies (L.) Karst. Oecologia, 108, 771-776. http://dx.doi.org/10.1007/BF00329054

[19] Stevens, L. (1985) Aspects of Invertebrate Herbivore Community Dynamics on Tamarix chinensis and Salix exigua in the Grand Canyon. MS Thesis, Northern Arizona University, Flagstaff.

[20] Levine, J., Vilà, M., D’Antonio, C.M., Dukes, J.S., Grigulis, K. and Lavorel, S. (2003) Mechanisms Underlying the Impacts of Exotic Plant Invasions. Proceedings of the Royal Society B: Biological Sciences, 270, 775-781. http://dx.doi.org/10.1098/rspb.2003.2327

[21] Lesica, P. and DeLuca, T. (2004) Is Tamarix Allelopathic? Plant and Soil, 267, 357-365. http://dx.doi.org/10.1007/s11104-005-0153-y

[22] Mawson, C. (1948) Honeydew on Lime Trees. Nature, 161, 176. http://dx.doi.org/10.1038/161176b0

[23] Dighton, J. (1978) Effects of Synthetic Lime Aphid Honeydew on Populations of Soil Organisms. Soil Biology \& Biochemistry, 10, 369-376. http://dx.doi.org/10.1016/0038-0717(78)90060-3

[24] Dighton, J. (1978) In Vitro Experiments Simulating the Possible Fates of Aphid Honeydew Sugars in Soil. Soil Biology \& Biochemistry, 10, 53-57. http://dx.doi.org/10.1016/0038-0717(78)90010-X

[25] Grier, C. and Vogt, D. (1990) Effects of Aphid Honeydew on Soil Nitrogen Availability and Net Primary Production in an Alnus rubra Plantation in Western Washington. Oikos, 57, 114-118. http://dx.doi.org/10.2307/3565744

[26] Dickson, L. and Whitham, T. (1996) Genetically-Based Plant Resistant Traits Affect Arthropods, Fungi, and Birds. Oecologia, 106, 400-406. http://dx.doi.org/10.1007/BF00334568

[27] Batra, R.C., Sharma, D.R., Kumar, R. and Arora, P.K. (2002) Association of Citrus Whitefly Population with Sooty Mould. Indian Journal of Citriculture, 1, 171-175.

[28] Dik, A. and van Pelt, J. (1993) Interaction between Phyllosphere Yeasts, Aphid Honeydew and Fungicide Effectiveness in Wheat under Field Conditions. Plant Pathology, 41, 661-675. http://dx.doi.org/10.1111/j.1365-3059.1992.tb02550.x

[29] Hillocks, R. and Brettell, J. (1993) The Association between Honeydew and Growth of Cladosporium herbarum and Other Fungi on Cotton Lint. Tropical Science, 33, 121-129.

[30] Beauchamp, V., Stromberg, J.C. and Stutz, J.C. (2005) Interactions between Tamarix ramosissima (Saltcedar), Populus fremontii (Cottonwood), and Mycorrhizal Fungi: Effects on Seedling Growth and Plant Species Coexistence. Plant and Soil, 275, 221-231. http://dx.doi.org/10.1007/s11104-005-1740-7

[31] Elgersma, K. and Ehrenfeld, J. (2011) Linear and Non-Linear Impacts of a Nonnative Plant Invasion on Soil Microbial 
Community Structure and Function. Biological Invasions, 13, 757-768. http://dx.doi.org/10.1007/s10530-010-9866-9

[32] National Weather Service Forecast Office (NWSFO) (2008) National Oceanic and Atmospheric Administration. http://www.weather.gov/climate/xmacis.php?wfo=psr

[33] SAS Institute (2008) JMP Version 7.0.2. SAS Institute Inc., Cary.

[34] Rice, W. (1989) Analyzing Tables of Statistical Tests. Evolution, 43, 223-225. http://dx.doi.org/10.2307/2409177

[35] Hendrix, D., Wei, Y. and Leggett, J.E. (1992) Homopteran Honeydew Sugar Composition Is Determined by both the Insect and Plant Species. Comparative Biochemistry and Physiology Part B, 101, 23-27. http://dx.doi.org/10.1016/0305-0491(92)90153-I

[36] Byrne, D., Hendrix, D.L. and Williams III, L.H. (2003) Presence of Trehalulose and Other Oligosaccharides in Hemipteran Honeydew, Particularly Aleyrodidae. Physiological Entomology, 28, 144-149. http://dx.doi.org/10.1046/j.1365-3032.2003.00310.x

[37] Fischer, M. and Shingleton, A. (2001) Host Plant and Ants Influence the Honeydew Sugar Composition of Aphids. Functional Ecology, 15, 544-550. http://dx.doi.org/10.1046/j.0269-8463.2001.00550.x

[38] Mortenson, S.G., Weisberg, P.J. and Stevens, L.E. (2011) The Influence of Floods and Precipitation History on Tamarix Establishment in Grand Canyon, Arizona: Consequences for Flow Regime Restoration. Biological Invasions, 14, 1061-1076.

[39] Schafer, M. and Kotanen, P. (2004) Impacts of Naturally-Occurring Soil Fungi on Seeds of Meadow Plants. Plant Ecology, 175, 19-35.

[40] Stevens, L.E. (1989) The Status of Ecological Research on Tamarisk (Tamaricaceae: Tamarix ramosissima) in Arizona. In: Kunzman, M.R., Johnson, R.R. and Bennett, P.S., Eds., Tamarisk Control in Southwestern United States, Cooperative National Park Resources Study Unit Special Report Number 9, Tucson, 99-105.

[41] Reynolds, L. and Cooper, D. (2010) Environmental Tolerance of an Invasive Riparian Tree and Its Potential for Continued Spread in the Southwestern US. Journal of Vegetation Science, 21, 733-743.

[42] Keane, R. and Crawley, M. (2002) Exotic Plant Invasions and the Enemy Release Hypothesis. Trends in Ecology and Evolution, 17, 164-170. http://dx.doi.org/10.1016/S0169-5347(02)02499-0

[43] Abbott, K. and Green, P. (2007) Collapse of an Ant-Scale Mutualism in a Rainforest on Christmas Island. Oikos, 116, 1238-1246. http://dx.doi.org/10.1111/j.0030-1299.2007.15629.x

[44] O’Dowd, D., Green, P.T. and Lake, P.S. (2003) Invasional "Meltdown" on an Oceanic Island. Ecology Letters, 6, 812-817. http://dx.doi.org/10.1046/j.1461-0248.2003.00512.x

[45] Simberloff, D. and Von Holle, B. (1999) Positive Interactions of Nonindigenous Species: Invasional Meltdown? Biological Invasions, 1, 21-32. http://dx.doi.org/10.1023/A:1010086329619

[46] Stromberg, J.C. (1998) Functional Equivalency of Saltcedar (Tamarix chinensis) and Fremont Cottonwood (Populus fremontii) along a Free-Flowing River. Wetlands, 18, 675-686. http://dx.doi.org/10.1007/BF03161682

[47] Stevens, L. and Waring, G. (1985) The Effects of Prolonged Flooding on the Riparian Plant Community in Grand Canyon. In: Johnson, R.R., Ed., Riparian Ecosystems and Their Management: Reconciling Conflicting Uses, U.S. Forest Service, Tucson, General Technical Report RM-120, 81-86.

[48] DeLoach, C., Carruthers, R.I., Lovich, J.E., Dudley, T.L. and Smith, S.D. (2000) Ecological Interactions in the Biological Control of Saltcedar (Tamarix spp.) in the United States: Toward a New Understanding. In: Spencer, N.R., Ed., Proceedings of the X International Symposium on Biological Control of Weeds, Montana State University Press, Bozeman, 819-873.

[49] Shafroth, P., Friedman, J.M. and Ischinger, L.S. (1995) Effects of Salinity on Establishment of Populus fremontii (Cottonwood) and Tamarix ramosissima (Saltcedar) in Southwestern United States. Great Basin Naturalist, 55, 58-65.

[50] Katz, G. and Shafroth, P. (2003) Biology, Ecology, and Management of Elaeagnus angustifolia L. (Russian olive) in Western North America. Wetlands, 23, 763-777. http://dx.doi.org/10.1672/0277-5212(2003)023[0763:BEAMOE]2.0.CO;2

[51] Wiesenborn, W. (2003) Variation in Opsius stactogalus (Homoptera: Cicadellidae) Egg Density among Tamarix ramosissima (Tamaricaceae) Trees. Pan Pacific Entomologist, 79, 38-44.

[52] Stevens, L.E., Burke, K.J., Spence, J.R., Pilkington, L. and Hughes, C. (2015) Colorado River Riparian Ecosystem Rehabilitation in Glen Canyon National Recreation Area, Arizona. In: Eleventh Biennial Symposium on Research on the Colorado Plateau, U.S. Geological Survey, Flagstaff, in Press. 